\title{
The Implementation of Internet-Based Activities in Teaching Listening Skill
}

\section{Tri Wahyuni Chasanatun, S.S, M.Pd}

\section{Abstract}

This article aims to discuss about the used of internet-based activities in teaching listening skill. Internet technology is widely spead through all over the world. Many people used internet as their sources in gaining more information. Moreover for the teachers or lecturers of English Language Teaching class, they are using internet technology as their sources or media in teaching and learning process. Hopefully, this article can give contribution to the teacher and lecturer in teaching listening skill.

Keyword:internet-based activities, listening skill

\section{INTRODUCTION}

IT or Information and Technology

is an old term and is still widely used in

some circles. Information and Communication Technology, or ICT, refers to technological tools that are used to communicate and to manage information. According to Graham Davies (1982; 1985) "ICT has been making a contribution to modern language learning and teaching since the early 1960s and quite significantly so since the early 1980s: v. the flurry of publications in the early 1980s".
According to the teacher ${ }^{\text {ee }} \mathrm{s}$ comments-at conferences, in papers and on the internet mailing lists dedicated to ELT - they seem to use interenet technology just for: development, updating language skills, finding materials, learning about computer applications, keeping in touch with friends and colleagues, teaching, working on class projects and activities, and just having fun.

\section{LISTENING}

Hornby (2007: 750) states that listening is the act of single who listens 
(pays attention to somebody or something that you can hear). The listener should identify, comprehend and interpret the information they have heard and used that kind of information. Moreover Dick and Carey (1996: 91) state that without any background knowledge, listener will be dependent upon the linguistic knowledge to interpret massage. Background knowledge is needed in the process of listening. It makes the listener easy to interpret and comprehend all messages they hear.

Prior knowledge is perhaps even more important in listening. The idea of prior knowledge is one part of the cognitive model of language processing. That model says that when people listen or read, we process the information we hear both top-down and bottom-up. Top-down means using our prior knowledge and experiences; we know certain things about certain topics and situations and use that information to understand. Bottom-up processing means using the information we have about sounds, word meanings, and discourse markers like first, then and after that to assemble our understanding of what we read or hear one step at a time.

Students obviously need both bottom-up and top-down processing skills in listening as well. Students must hear some sounds (bottom-up processing), hold them in their working memory long enough (a few seconds) to connect them to each other and then interpret what they ve just heard before something new comes along. At the same time, listeners are using their background knowledge (top-down processing) to determine meaning with respect to prior knowledge and schemata.

From those explanation above, we can say that. Listening is more than just hearing. It needs background knowledge to identify, comprehend, and interpret the information that the listeners have heard.

\section{THE WAY HOW PEOPLE LISTEN}

The listeners can start by listening for main ideas. It means that the listener wants to get a general idea of what is being said. The details are less important. The next type is listening for details. It is something we do every day. The important reason for listening is listening and making inferences. Speakers do not always say exactly what they mean. That is, important aspects of meaning are sometimes implied rather than stated. Listeners have to "listen between the lines" to figure out what really is meant.

According to Michael Rost (1991: 4) "even though a person may have good listening ability, he or she may not always be able to understand what is being said. The underlying action for successful listening is decision making. The listener must make these kinds of decision: (1) 
what kind of situation is this? ; (2) What is my plan for listening? ; (3) What are the important words and units of meaning? ; (4) does the message make sense? He also states that successful listening requires making effective „real time ${ }^{\text {ee }}$ decisions about these questions".

\section{TEACHING LISTENING USING INTERNET-BASED ACTIVITIES}

In teaching listening, the teacher can apply top-down strategies. Top-down strategies are listener based; the listener taps into background knowledge of the topic, the situation or context, the type of text, and the language. This background knowledge activates a set of expectations that help the listener to interpret what is heard and anticipate what will come next. This strategies teachers start by telling the students the story or playing the recorded material and asking them to memorize the whole story and later learn to deal with individual words. These strategies apply three procedures. They are (1) pre listening stages, (2) while-listening stages, (3) post listening stages. Underwood (1997: 30) states that "in the pre-listening stages, the students should be ,tuned in so that they know what to expect both in general and for particular tasks". Furthermore, Underwood (1997: 31) indicates that some activities that can be applied in the prelistening stage, such as (1) the teacher giving background information, (2) the students reading something relevant, (3) the students looking at pictures, (4) discussion of the topic or situation, (5) a question and answer session, (6) written exercises, (7) following the instructions for the while-listening activity, consideration of how the while-listening activity will be done. This activities provides students with some background information that can help the students understand what they listen more easily.

There are some steps in creating internet-based activities. Before teachers or lecturers design an internet based activity, they need to decide on their objectives. It can be; purposes, what kind of activities, how can teacher communicate with students, etc. Meanwhile, in creating a task, the teacher can look through the course book, creating an activities that can make the students challenged and engaged in all activities. Analyzing the shortcomings of this activities will frequently suggest an area of the internet to use for the task; letters that go nowhere hint at e-mail; out-of-date newspaper articles imply use of the Web, doing a discussions of films that never seen; debating or defending commonly held opinions carves a synchronous multicultural medium such as chat or discussion boards. 
The teacher should determined the specific application or applications that will be used for every activity, the next step is to find the particular area or site; specific room, mailing list or web site.

According to Harmer (1985) "listening needs to be taught in every language teaching, moreover foreign language. It is because, as a learners to be able to speak and write English well they need to listen to the native speaker first in order to make them more fluent in English learning. As people learning their mother tongue, children listen to the other people around them before they begin to speak.

In teaching listening, the multimedia content available on the Web is various. There is anything and everything from live concerts and interviews to time-honoured radio serials. Local radio stations may even be available over the Web. Most of the commercial news agencies offer up-to-the-minute television and radio broadcasts to provide the fullest resources, and offer worksheets and comprehension activities.

There are basically two types of video and audio files in the Net:

1) Some files or clips required to click on the file name, and then wait for download to the machine before play it back. This includes files whose names end in extensions like: .qt or .mov; .avi; .wav.
Downloading these files can sometimes take several minutes over a medium-speed connection, but then they can be saved to a file and listened to several times.

2) Other clips play back immediately, over a live connection. The most popular types requires a special helper application called the RealPlayer, which plays RealAudio and Realvideo files with extensions such as .ra or .ram. The user must have a fast, stable connection in order to really enjoy quality sound, since files cannot be saved and listened to offline . But this technology makes live video a reality.

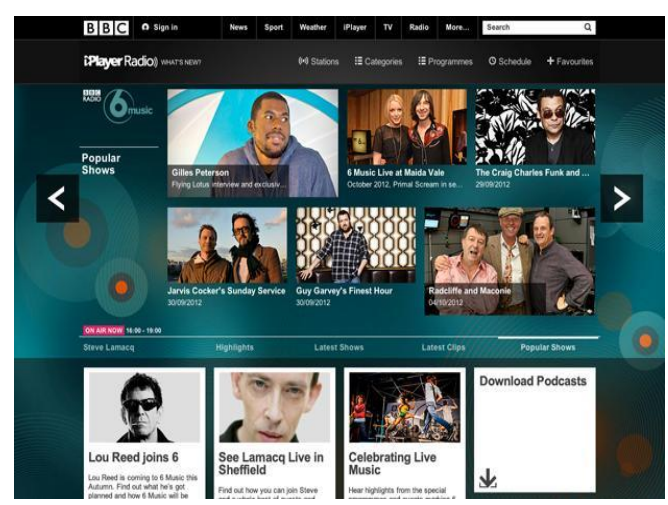

The listening activities can be:

Focus on describing music, matching themes to films. The duration is about 30-45 minutes with midintermediate and above students. The teacher or lecturer select the web site from which they wish to download audio files of a variety of theme tunes from five different 
films. The lecturer or teacher check for copyright restrictions and seek permission if necessary. They can prepare more than one audio file per film. After that the teacher or lecturer can make such kind of handouts of the film synopses; pre-teach relevant music vocabulary; download some actual film clips.

As this activitiy focuses on film or music, it does not involve any comprehension of listening texts as such. Instead, it uses theme music as a way of getting students discussing how music relates to imagery and action.

The activities begin by dividing the students into some groups to each computer. The teacher or lecturer then asks the students to read the short synopses directly from the computer or handout. After they have finished reading the synopses and get new vocabulary, the teacher or lecturer click on one of the audio files at random. The task for students is to guess which film the music clip is from. They must guess and state their

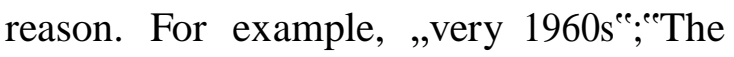
song is so sad and melodice; , It has a great dance rhythm ${ }^{\text {ee }}$. At the end of the lesson, teacher or lecturer tell the students about which music clip is from which film and the students vote for the music clip they think best reflects the film synopsis.

INTERNET-BASED MATERIAL FOR TECHING LISTENING
One of the sources that can be used as the listening material is from The BBC World Service Learning English. The teacher can choose one of the material from BBC. Online resources for developing listening skills (e.g. audio and video, podcasts, video clip tools), and some suggested strategies for improving listening ability can be seen as follows:

\section{The Internet - A Goldmine of Listening Materials}

Internet prepare an unending stream of audio and video lessons, television and radio broadcasts, including news and documentaries, and music through different sources. In addition to this, a new generation of internet tools are available (Skype, podcasts, online webcasts and conferences, voice boards). Moreover, social networks create multiple opportunities for authentic communication.

\section{Audio and Video}

The principal benefits of online audio and video start with the range of material in terms of subject matter, accent of the speaker, and length. Some of the activities are listening to the news, listening to $\mathrm{TV}$ broadcasts. It will require learners to set aside quite a lot of time. 
3. Online audio and video news.

Online listening activities are divided into those that are specifically scripted for English learners, while others consist of authentic materials which have been specially selected. The BBC World Service International Radio News is completed with a short summary, transcript, and a glossary of some vocabulary terms. For example:

\section{a. Listen and Watch http://learnenglish.britishcouncil.o rg/en/listen-and-watch}

Five-minute audio reports and transcripts on subjects such as famous people, pop music, and entertainment. Students can listen to or watch news on the computer, or download audio and video files to their mp3 players. Audio and video materials are accompanied by language practice activities that learners can do on their computers while they listen or watch, or print out and do them when they want to.

\section{b. The BBC News http://www.bbc.co .uk/news/video_and_audio/}

A very useful thing about the $\mathrm{BBC}$ audio/video is that it contains recordings of individual stories which are one to two minutes long. Learners can choose which topic they would like to listen to. There is a wide variety of different categories - Business, Technology, World News, UK News, Technology, and so on. The BBC site is predominantly British English.

\section{c. CNN News http://edition. $\underline{\text { cnn.com / video/ }}$}

Similarly to the BBC site, learners can listen to clips of individual news items or to whole programmes. The $\mathrm{CNN}$ site is predominantly American English.

\section{d. Breaking News English} http://www.breakingnewsenglish.c om/

This site has news articles on different topics along with a sound recording of the article accompanied by a resource book with ready-to-use ESL/EFL lessons and worksheets that learners can work with on their own.

\section{e. Monthly News Digest Online http://www.englishclub.com/li stening/news.htm}
A "news digest" is a summary of news stories. Each month EnglishClub creates a digest in 
easy English with four short audio news reports from the past 30 days. Monthly News Digest Online has been designed so that English learners can use it on their own not only for practising listening but for reading, writing, and even speaking. It is posted on the first day of each month and includes audio feeds, texts, and exercises. Some tips for listening to the summary of news are: Prelistening: Try to guess what words might fit in the blanks.Listening: Listen to the audio three times: 1) to get the gist, 2) to fill in the cloze passages, and 3) to check answers.

\section{CONCLUSION}

According to Hornby (2007: 750) listening is the act of single who listens (pays attention to somebody or something that you can hear). The listener should identify, comprehend and interpret the information they have heard and used that kind of information. Nowdays, many teachers especially for english teacher tend to choose internet as their material resources. They seem to use interenet technology just for: development, updating language skills, finding materials, learning about computer applications, keeping in touch with friends and colleagues, teaching, working on class projects and activities, and just having fun.

One of the sources that can be used as the listening material is from The BBC World Service Learning English. The teacher can choose one of the material from BBC. Online resources for developing listening skills (e.g. audio and video, podcasts, video clip tools).

There are some steps for the teacher in creating internet-based activities. Before teachers or lecturers design an internet based activity, they need to decide on their objectives. It can be; purposes, materials, what kind of activities, how can teacher communicate with students, etc. Meanwhile, in creating a task, the teacher can look through the course book, creating an activities that can make the students challenged and engaged in all activities.

\section{References}

Davies G. \& Higgins J. (1985) Using computers in language learning: a teacher's guide, London: CILT. Available at: http://www.teachingenglish.org.uk/ think/knowledge-wiki/ict

Dick, Walter, Lou Carry, and James D, Carry. 2001. The Systematic Design of Instruction: Fifth Edition. Toronto: Addition-Wesley Educational Publisher Inc.

Hornby, 1995. Advance Learners' Dictionary. New York. Oxford University Press. 
http://id.search.yahoo.com/search;_ylt=An ZEz1jqHHlqK2sbMjreXZFuf445? $\mathrm{vc}=\& \mathrm{p}=$ procedure+teaching + listeni ng+using+podcast\&toggle $=1 \&$ cop $=$ mss\&ei $=U T F-8 \& f r=y f p-t-713$ last visited on Thursday 04/11/2010/ $19.00 \mathrm{pm}$.

Rost, M. (1991). Listening in action: Activities for developing listening in

language teaching. Englewood Cliffs, NJ: Prentice Hall.

Peterson, E. (2010). Internet-based resources for developing listening. Studies in Self-Access Learning Journal, 1 (2). 139-154.Available at

http://sisaljournal.org/archives/sep1 $0 /$ peterson/
Brown S. (2006) Teaching Listening. New York. Cambridge University Press.

Teeler D \& Gray P. (2005) (How to Use the Internet in ELT).Longman. Underwood, M. 1993. Teaching Listening. London. Longman.

Information and Communication Technologies. Available at http://www.education.tas.gov.au/en glish/technology.htm

Introduction to new technologies and how they can contribute to language learning and teaching. Available at: http://www.ict4lt.org/en/en_mod11.htm\#anchor158435. 